\title{
Antimicrobial Efficacy of Fruit Peels Eco-Enzyme against Enterococcus faecalis: An In Vitro Study
}

\author{
Hetal Ashvin Kumar Mavani ${ }^{1}{ }^{\mathbb{D}}$, In Meei Tew ${ }^{1, * \mathbb{C}}$, Lishen Wong ${ }^{1}{ }^{\mathbb{D}}$, Hsu Zenn Yew ${ }^{1}$, \\ Alida Mahyuddin ${ }^{2}$, Rohi Ahmad Ghazali ${ }^{3}$ and Edmond Ho Nang Pow ${ }^{1,4}$ \\ 1 Department of Restorative Dentistry, Faculty of Dentistry, The National University of Malaysia, \\ Kuala Lumpur 50300, Malaysia; hetalmav81@ukm.edu.my (H.A.K.M.); wonglishen@ukm.edu.my (L.W.); \\ hz_yew@ukm.edu.my (H.Z.Y.); ehnpow@hku.hk (E.H.N.P.) \\ 2 Department of Family Dentistry, Faculty of Dentistry, The National University of Malaysia, \\ Kuala Lumpur 50300, Malaysia; alida@ukm.edu.my \\ 3 Department of CITRA \& Teaching, Faculty of Health Sciences, The National University of Malaysia, \\ Kuala Lumpur 50300, Malaysia; rohi@ukm.edu.my \\ 4 Division of Restorative Dental Sciences, Faculty of Dentistry, University of Hong Kong, Hong Kong, China \\ * Correspondence: inmeei@ukm.edu.my; Tel.: +603-92-897-795; Fax: +603-26-982-944
}

Received: 17 June 2020; Accepted: 13 July 2020; Published: 15 July 2020

\begin{abstract}
Sodium hypochlorite $(\mathrm{NaOCl})$, an effective endodontic irrigant against Enterococcus faecalis $(\mathrm{EF})$, is harmful to periapical tissues. Natural pineapple-orange eco-enzymes (M-EE) and papaya eco-enzyme (P-EE) could be potential alternatives. This study aimed to assess the antimicrobial efficacy of M-EE and P-EE at different concentrations and fermentation periods against EF, compared to $2.5 \% \mathrm{NaOCl}$. Fermented M-EE and P-EE (3 and 6 months) at various concentrations were mixed with EF in a 96-well plate incubated for $24 \mathrm{~h}$ anaerobically. Minimum inhibitory concentration (MIC) and minimum bactericidal concentration (MBC) of M-EE and P-EE were determined via EF growth observation. EF inhibition was quantitatively measured and compared between different irrigants using the one-way analysis of variance (ANOVA), and different fermentation periods using the independent-samples T-test. M-EE and P-EE showed MIC at 50\% and MBC at $100 \%$ concentrations. There was no significant difference in antimicrobial effect when comparing M-EE and P-EE at 50\% and $100 \%$ to $2.5 \% \mathrm{NaOCl}$. P-EE at 6 months fermentation exhibited higher EF inhibition compared to 3 months at concentrations of $25 \%(p=0.017)$ and $0.78 \%(p=0.009)$. The antimicrobial properties of M-EE and P-EE, at both $100 \%$ and $50 \%$ concentrations, are comparable to $2.5 \% \mathrm{NaOCl}$. They could therefore be potential alternative endodontic irrigants, but further studies are required.
\end{abstract}

Keywords: eco-enzyme; endodontics; Enterococcus faecalis; fruit peels; root canal irrigants; sodium hypochlorite

\section{Introduction}

Endodontic treatment aims to eradicate infection and prevent reinfection within the root canal system. However, the complete elimination of debris and bacteria in the root canal system is impossible because of the complexity of the root canal anatomy [1]. The remnant bacteria, especially Enterococcus faecalis, are believed to be the most resistant microorganism that contribute to the persistent periradicular lesion after root canal treatment [2]. Different virulence factors, such as aggregation substance, lipoteichoic acid, and pheromones, have facilitated Enterococcus faecalis to survive in dentinal tubules up to $400 \mu \mathrm{m}$ depth in a nutrient deficiency ecology environment and cause secondary infection [3].

The use of endodontic irrigants as an adjunct to mechanical debridement during root canal treatment is often emphasized for optimizing root canal disinfection. Among all endodontic irrigants, 
sodium hypochlorite $(\mathrm{NaOCl})$ is widely accepted as the "gold standard", because of its potent antibacterial and proteolytic activity. Its antibacterial efficacy, especially against Enterococcus faecalis, has been well established [4]. It is primarily attributed to chlorine, which induces irreversible oxidation of bacterial enzyme and disrupts the metabolic function of bacterial cells [5]. Nevertheless, its toxic effects on vital tissues in the event of accidental extrusion beyond root canal space have been documented. Damage could irreversibly occur in periradicular tissues involving soft tissue spaces and the neurovascular structures [6].

Natural plant extracts have been studied as a potential substitute for $\mathrm{NaOCl}$ as endodontic irrigants [7-10]. Fruit peels have displayed antimicrobial activities against a wide range of microorganisms, including Enterococcus faecalis [11,12]. Following fermentation, the antibacterial properties of fruit peels are further enhanced as organic substances are decomposed, yielding secondary metabolites known as bioactive compounds or phytochemicals $[13,14]$. The extraction of enzymes, organic acids, and phenolic compounds through the fermentation process is preferred over conventional methods that require costly solvents, involve the possible degradation of heat-labile compounds, and through which it is difficult to obtain high purity extracts [15]. Thus, fermented fruit peels, known as eco-enzyme, could be an alternative endodontic irrigant.

An eco-enzyme extracted from fermented unripe papaya (Carica papaya) peels is found to be rich in papain, which exhibits significant antibacterial efficacy against Enterococcus faecalis [16]. A study by Duarte and co-workers reported $0.8 \%$ of papain is equally effective as $1.0 \% \mathrm{NaOCl}$ in inhibiting Enterococcus faecalis growth [17]. It has less harmful effects on vital tissues compared to $\mathrm{NaOCl}$, as its proteolytic activities selectively target unhealthy tissues where $\alpha 1$-antitrypsin plasmatic antiprotease is absent [18]. Besides, phytochemicals found in the papaya peel eco-enzyme demonstrate a potential anti-inflammatory effect, which minimizes the chronic inflammatory process and tissue destruction, particularly in cases of apical periodontitis [19].

Similarly, eco-enzyme derived from pineapple (Ananas comosus) and orange (Citrus aurantium L.) peels have been shown to have antimicrobial as well as anti-inflammatory properties [20]. The synergistic effect of the two eco-enzymes increases the potency of their antimicrobial activity against a wide range of bacteria [21]. The high content of polyphenolic compounds and flavonoids in pineapple and orange peel extracts are found to be responsible for their excellent antimicrobial and antioxidant activities [22,23]. Bromelain from pineapple extracts is shown to be effective in killing Enterococcus faecalis by disrupting the peptidoglycan and polysaccharide components of bacterial cell membranes [24].

Numerous previous studies have looked into the antibacterial properties of different endodontic irrigants available on the market [25-28]. However, studies on eco-enzyme fermented from fruits and/or its peel as alternative endodontic irrigants are lacking. Hence, this study aimed to investigate the potential antibacterial activity using fermented fruit peel wastes (a mixture of pineapple-orange peel extracts and papaya peel extracts) at different concentrations and fermentation periods against Enterococcus faecalis in comparison to $\mathrm{NaOCl}$.

\section{Materials and Methods}

Ethical approval was obtained from the research ethical committee of The National University of Malaysia (UKM PPI/111/8/JEP-2018-660) to conduct this in vitro study.

\subsection{Preparation of Eco-Enzyme Extracts}

Two types of eco-enzyme extracts were prepared in this study according to the method described by Arun and Sivashanmugam (2017) [20]: (1) a mixture of orange peel (Citrus aurantium) and pineapple peel (Ananas comosus) eco-enzyme extract (M-EE) at four to six ratio and (2) papaya peel (Carica papaya) eco-enzyme extract (P-EE). Each eco-enzyme extract was prepared in triplicates by mixing $75 \mathrm{~g}$ fruit peels, $25 \mathrm{~g}$ molasses, and $250 \mathrm{~mL}$ tap water in airtight containers. Each of the mixtures was stored and fermented for 3 and 6 months. M-EE and P-EE with 100\% concentration after the fermentation period 
were sterile filtered and further diluted to a concentration of $50 \%, 25 \%, 12.5 \%, 6.25 \%, 3.13 \%, 1.56 \%$, and $0.78 \%$, respectively, for antimicrobial efficacy test against Enterococcus faecalis.

\subsection{Bacterial Strain}

Enterococcus faecalis ATCC ${ }^{\circledR} 29212^{\mathrm{TM}}$ bacterial strain was used in this study. The inoculum was prepared based on the Clinical and Laboratory Standards Institute (CLSI) protocol (2012) [29]. Enterococcus faecalis was cultured in brain-heart infusion (BHI) broth and incubated at $37^{\circ} \mathrm{C}$ with $95 \%$ relative humidity for $24 \mathrm{~h}$. The bacterial cell density was further adjusted to $0.5 \mathrm{McF}$ arland Standards $\left(1-2 \times 10^{6} \mathrm{CFU} / \mathrm{mL}\right)$.

\subsection{Determination of Minimal Inhibitory Concentration (MIC)}

Minimum inhibitory concentration (MIC) of both M-EE and P-EE extracts of different concentrations against Enterococcus faecalis was determined using CLSI (2012) protocol [29]. In brief, $50 \mu \mathrm{L}$ of each of the following solutions: $2.5 \% \mathrm{NaOCl}$ (positive control), $\mathrm{BHI}$ broth (negative control), $\mathrm{M}$-EE and P-EE with different concentrations at a 3 and 6 months fermentation period, were mixed with $50 \mu \mathrm{L}$ Enterococcus faecalis in a 96-well plate (Biologix, Selangor, Malaysia) and incubated under the anaerobic condition for $24 \mathrm{~h}$ at $37^{\circ} \mathrm{C}$. All samples were prepared in triplicates. The bacterial growth was observed with naked eyes and the appearance of the well plate was recorded as "no turbidity observed" (no bacterial growth) or "turbidity observed" (bacterial growth). Bacterial growth was also quantitatively measured using ELISA microplate reader (Thermo Fisher Scientific, Waltham, MA, USA) at $625 \mathrm{~nm}$ wavelength. Mean optical density (OD) of positive, negative, and tested groups were recorded and compared with its corresponding untreated control wells.

\subsection{Determination of Minimal Bactericidal Concentration (MBC)}

Minimal bactericidal concentration (MBC) of M-EE and P-EE against Enterococcus faecalis was determined by taking samples with no apparent bacterial growth in wells from MIC tests and cultured on BHI agar plates. After an incubation period of $24 \mathrm{~h}$ at $37{ }^{\circ} \mathrm{C}$ with $95 \%$ relative humidity, the agar plates containing M-EE and P-EE were inspected with the naked eye for any bacterial colonies growth.

\subsection{Statistical Analysis}

Results were analyzed with the data collected from M-EE and P-EE of different concentrations at a 3 and 6 months fermentation period, $\mathrm{NaOCl}$, and $\mathrm{BHI}$ broth, using Statistical Package for the Social Sciences (SPSS) Version 23 software (IBM, Armonk, NY, USA). The results from direct visualization in MIC and MBC tests were descriptively documented. The comparisons of mean difference in OD between $\mathrm{M}$-EE and P-EE of different concentrations with 2.5\% $\mathrm{NaOCl}$ (positive control group) and $\mathrm{BHI}$ broth (negative control group) at the two fermentation periods were tested using one-way analysis of variance (ANOVA). A univariate ANOVA was used to test within-subject effects and Bonferroni multiple comparisons were performed to detect differences in mean OD difference over the M-EE, P-EE, positive and negative control groups. The comparison of the mean difference between two fermentation periods for each tested group was analyzed using the independent-samples T-test. All tests were set at a significant level of 0.05 .

\section{Results}

The MIC of M-EE and P-EE at various concentrations over 3 and 6 months fermentation periods are shown in Tables 1 and 2. Both M-EE and P-EE showed Enterococcus faecalis growth inhibition at concentrations of $50 \%$ and $100 \%$ at a 3 and 6 months fermentation period under direct visualization (Figures 1 and 2). 
Table 1. Enterococcus faecalis growth at different concentrations of pineapple-orange eco-enzymes (M-EE).

\begin{tabular}{ccccccccc}
\hline Concentration (\%) & $\mathbf{1 0 0}$ & $\mathbf{5 0}$ & $\mathbf{2 5}$ & $\mathbf{1 2 . 5}$ & $\mathbf{6 . 2 5}$ & $\mathbf{3 . 1 3}$ & $\mathbf{1 . 5 6}$ & $\mathbf{0 . 7 8}$ \\
\hline $\begin{array}{c}3 \text { months } \\
\text { fermentation } \\
\begin{array}{c}6 \text { months } \\
\text { fermentation }\end{array}\end{array}$ & 1 & 1 & 2 & 2 & 2 & 2 & 2 & 2 \\
\hline
\end{tabular}

1: No turbidity observed. 2: Turbidity observed.

Table 2. Enterococcus faecalis growth at different concentrations of papaya eco-enzyme (P-EE).

\begin{tabular}{ccccccccc}
\hline Concentration $(\%)$ & $\mathbf{1 0 0}$ & $\mathbf{5 0}$ & $\mathbf{2 5}$ & $\mathbf{1 2 . 5}$ & $\mathbf{6 . 2 5}$ & $\mathbf{3 . 1 3}$ & $\mathbf{1 . 5 6}$ & $\mathbf{0 . 7 8}$ \\
\hline $\begin{array}{c}3 \text { months } \\
\text { fermentation } \\
\begin{array}{c}6 \text { months } \\
\text { fermentation }\end{array}\end{array}$ & 1 & 1 & 2 & 2 & 2 & 2 & 2 & 2 \\
\hline
\end{tabular}

1: No turbidity observed. 2: Turbidity observed.

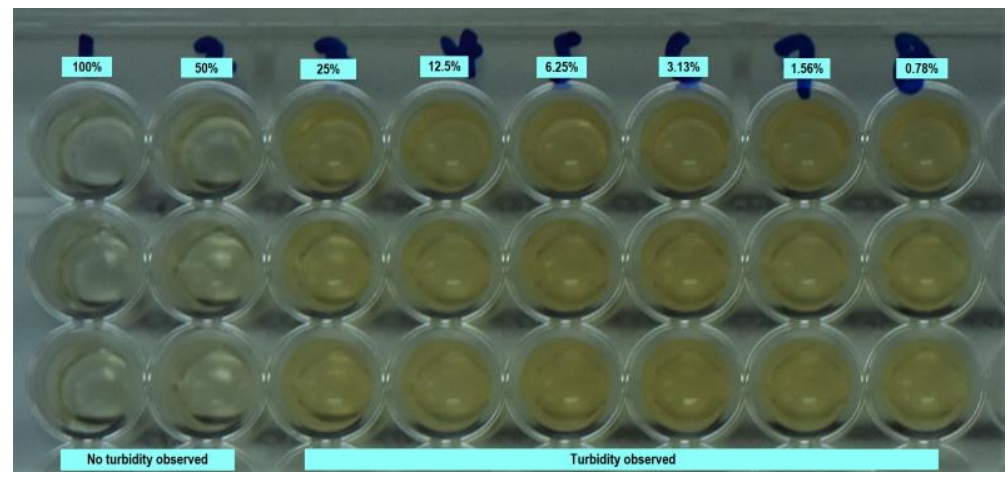

Figure 1. Observation of Enterococcus faecalis growth in a 96-well plate at different concentrations of M-EE fermented for 3 months.

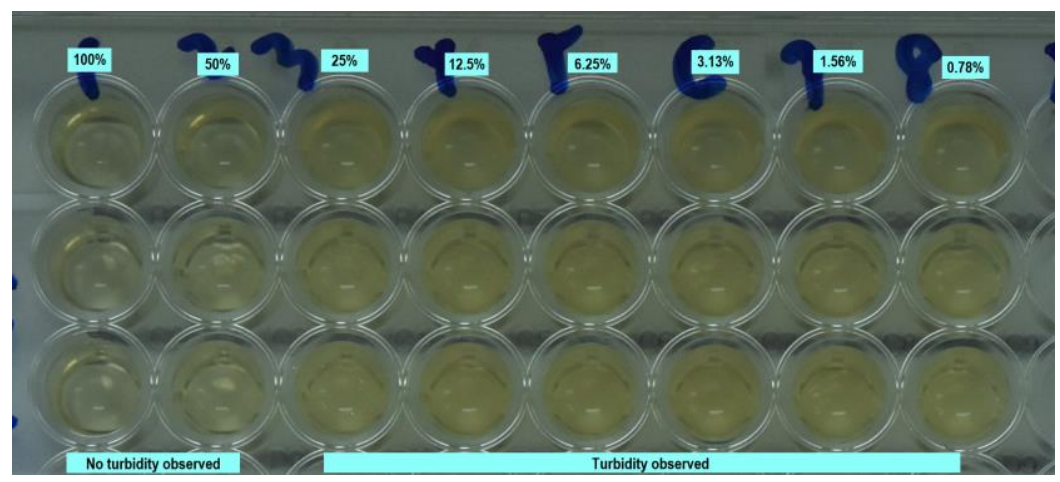

Figure 2. Observation of Enterococcus faecalis growth in a 96-well plate at different concentrations of P-EE fermented for 3 months.

The mean difference in optical density $(\triangle \mathrm{OD})$ of $2.5 \% \mathrm{NaOCl}, \mathrm{BHI}$ broth, and $\mathrm{M}$-EE of various concentrations at a 3 and 6 months fermentation period were compared and are illustrated in Figure 3. The $\triangle$ ODs of M-EE with $50 \%$ and $100 \%$ concentration at both fermentation periods were significantly lower compared to that of the BHI group $(p<0.05)$ and no significant difference was found when compared with that of the $\mathrm{NaOCl}$ group $(p>0.05)$. No significant differences in $\triangle \mathrm{OD}$ were found between the 3 months and 6 months fermentation groups across all concentrations of M-EE $(p>0.05)$. 


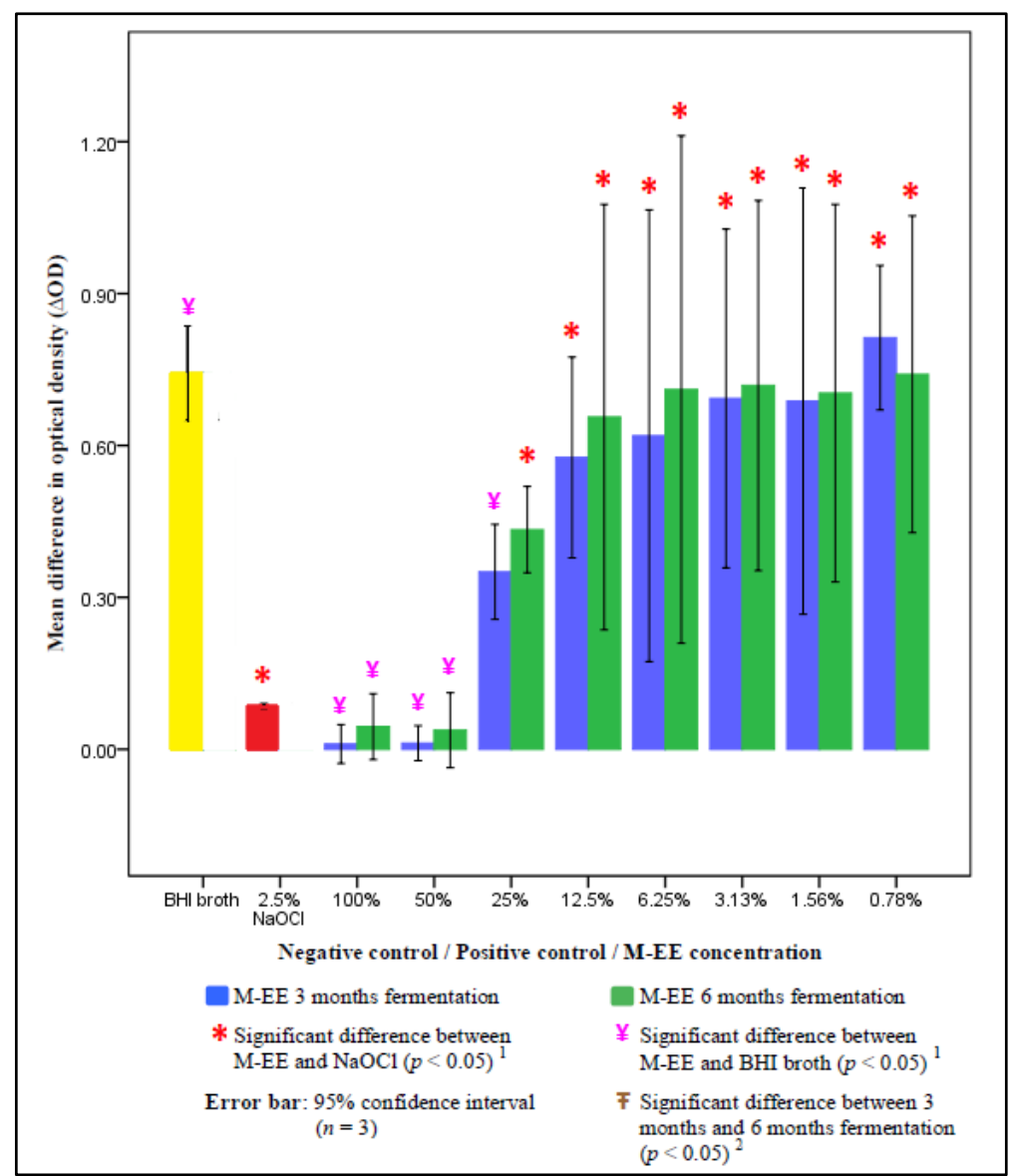

Figure 3. Mean difference in optical density between M-EE of different concentrations at 3 and 6 months fermentation, $\mathrm{NaOCl}$, and $\mathrm{BHI}$ broth. ${ }^{1}$ One-way analysis of variance (ANOVA): Difference between M-EE, NaOCL, and brain-heart infusion (BHI) broth $(p<0.05) .{ }^{2}$ Independent-samples T-test: Difference between fermentation periods $(p<0.05)$.

The results of $\triangle \mathrm{OD}$ between $2.5 \% \mathrm{NaOCl}, \mathrm{BHI}$ broth, and P-EE of various concentrations at a 3 and 6 months fermentation period are summarized in Figure 4. No significant difference in $\triangle \mathrm{OD}$ was found when comparing the $50 \%$ or $100 \%$ P-EE group with the $\mathrm{NaOCl}$ group $(p>0.05)$. Significantly higher efficacy against Enterococcus faecaelis was found in the 25\% $(p=0.017)$ and $0.78 \%(p=0.009)$ concentrations of P-EE at 6 months fermentation group compared to the 3 months fermentation group $(p<0.05)$. 


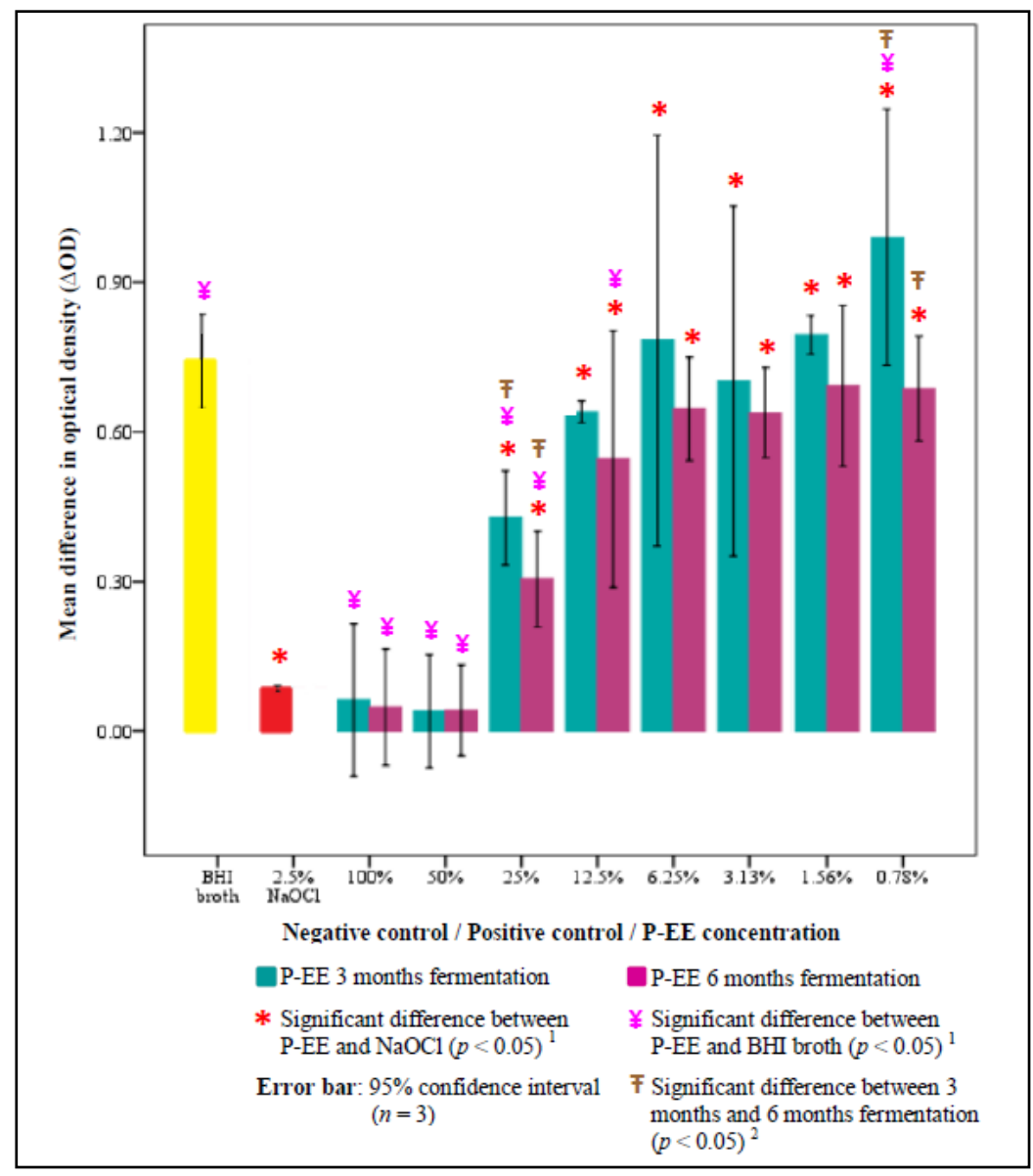

Figure 4. Mean difference in optical density between P-EE of different concentrations at 3 and 6 months fermentation, $\mathrm{NaOCl}$, and BHI broth. ${ }^{1}$ One-way ANOVA: Difference between P-EE, NaOCL, and BHI broth $(p<0.05) .{ }^{2}$ Independent-samples T-test: Difference between fermentation periods $(p<0.05)$.

The M-EE and P-EE at 50\% and 100\% concentrations with no apparent Enterococcus faecalis growth in MIC plate wells were further tested for MBC and the results are presented in Table 3. Only M-EE and P-EE at 100\% concentration had bactericidal activities against Enterococcus faecalis.

Table 3. Sensitivity against Enterococcus faecalis of M-EE and P-EE fermented for 3 and 6 months at 50\% and $100 \%$ concentrations.

\begin{tabular}{cccc}
\hline $\begin{array}{c}\text { Type of Endodontic } \\
\text { Irrigant }\end{array}$ & $\begin{array}{c}\text { Fermentation Period } \\
\text { (months) }\end{array}$ & $\begin{array}{c}\text { Concentration } \\
\mathbf{( \% )}\end{array}$ & $\begin{array}{c}\text { Sensitivity against } \\
\text { Enterococcus faecalis }\end{array}$ \\
\hline \multirow{2}{*}{ M-EE } & 3 & 100 & 1 \\
& 6 & 50 & 2 \\
& 3 & 100 & 1 \\
P-EE & 3 & 100 & 2 \\
& 6 & 50 & 2 \\
& & 100 & 1 \\
\hline
\end{tabular}

1: Sensitive. 2: Resistant. 


\section{Discussion}

Studies on the possible applications of natural substances in dentistry have increased remarkably in the last decade. Pineapple, orange, and papaya eco-enzymes have been widely investigated for therapeutic use in the management of periodontal diseases and caries removal [30-34]. To the best of our knowledge, this is the first in vitro study investigating the potential use of pineapple-orange and papaya eco-enzymes as endodontic irrigants.

MIC determination for M-EE and P-EE using the broth microdilution method in this study provides quantitative evaluations of their respective antimicrobial agents against Enterococcus faecalis [29,35], as compared to the agar disk-diffusion method in previous studies [36-38]. The broth microdilution method is preferred over the agar disk-diffusion method, as the former has better reproducibility and the confounding factor of diffusion potency of antimicrobial agents impregnated discs can be eliminated [39].

The concentration of $\mathrm{NaOCl}$ commonly used as endodontic irrigant ranges from $0.5 \%$ to $6.0 \%$ [40-42]. However, its optimal concentration for endodontic treatment is controversial [43]. Despite the fact that the usage of $5.25 \% \mathrm{NaOCl}$ is known as the gold standard [44], the choice of $2.5 \% \mathrm{NaOCl}$ as a positive control in this study is based on its equivalent antimicrobial efficacy to that of $5.25 \% \mathrm{NaOCl}$ [45]. This is supported by another study that demonstrated no significant difference in Enterococcus faecaelis biofilm eradication on dentine surface treated with $2.5 \%$ and $5.25 \% \mathrm{NaOCl}$ [46]. Moreover, $\mathrm{NaOCl}^{\prime} \mathrm{s}$ cytotoxicity is concentration dependent [47]. A NaOCl concentration of $2.5 \%$ has been shown to be less toxic to periapical tissues without compromising its antimicrobial properties [48]. Hence, the lowest possible clinically effective concentration should be used to ensure patient safety [49].

Although $\mathrm{NaOCl}$ appears to be the primary choice of endodontic irrigant, it cannot remove inorganic components of the smear layer which could only be removed by chelators, such as ethylenediaminetetraacetic acid (EDTA) [50]. However, when $\mathrm{NaOCl}$ is combined with EDTA, the availability of free chlorine in $\mathrm{NaOCl}$ is reduced and thus the antimicrobial efficacy of $\mathrm{NaOCl}$ against Enterococcus faecalis is compromised [51]. On the other hand, the addition of EDTA into the fruit peels eco-enzyme can enhance the enzyme proteolytic activities. This is in agreement with an in vitro study, which demonstrated the highest bromelain activity when bromelain was extracted using EDTA from pineapple peels [52]. This is also supported by another study by Chaiwut et al. [53], which investigated proteolytic components of papaya peel and reported that proteolytic activities of protease were activated by the addition of chelating agents such as EDTA.

The findings from this study showed that the antimicrobial efficacy of both M-EE and P-EE was concentration dependent. M-EE and P-EE with a minimum concentration of $50 \%$ had a comparable bacteriostatic effect on Enterococcus faecalis with $2.5 \% \mathrm{NaOCl}$, but the bactericidal effect was observed only in full strength M-EE and P-EE. These results are in agreement with previous studies that concluded better antimicrobial effects against endodontic pathogens at higher concentrations of fruit eco-enzyme $[54,55]$. With at least $50 \%$ concentration of M-EE or P-EE, hydrolytic enzymes, especially protease and amylase in M-EE and protease in P-EE, destroy the physical integrity of extracellular polymeric substances (EPS), the structure of Enterococcus faecalis, and lead to cell death [56].

Acetic acid, which was derived from the natural fermentation of fruit peels, also contributed to its antimicrobial properties. Though the concentration of acetic acid in M-EE and P-EE was not measured in this study, a previous study showed that its concentration increases with a longer fermentation period [57]. This was attributed to the hydrolysis of complex organic compounds into simpler compounds through anaerobic fermentation, resulting in the accumulation of low molecular weight acetic acid. Acetic acid can cross bacterial cell membranes because of the $\mathrm{pH}$ gradient, leading to the disruption of cellular metabolic activities of bacteria [58]. The higher osmotic pressure within bacterial cells also leads to water influx and cellular osmolysis [59].

A three-month fermentation period is a minimum prerequisite for fruit eco-enzyme preparation to achieve an optimal concentration of hydrolytic enzymes and acetic acid [60]. It is postulated that higher hydrolytic enzyme and acetic acid levels after a longer fermentation period would help to enhance the 
antimicrobial effects of fruit eco-enzyme [61]. The findings of P-EE conform to this theory as better antimicrobial efficacy was generally observed at a 6 months fermentation period compared to that of 3 months. Antimicrobial activity of papain is mainly related to enzymatic actions, such as amidase and esterase, which improves in a more acidic environment with a fermentation period of more than 3 months [62,63]. However, the aforementioned findings were not replicated in the current study of M-EE, which showed no significant enhancement of Enterococcus faecalis inhibition in fermentation periods longer than 3 months. This might be because the maturation of M-EE with peak hydrolytic enzyme occurred at 3 months fermentation, as a result of synergistic interactions between pineapple and orange peels eco-enzymes [64].

Ethanol, a byproduct of fruit peel fermentation, may theoretically have antibacterial efficacy against a wide range of pathological microorganisms. However, it has been shown that $25 \%$ of ethanol is required to inactivate Enterococcus faecalis effectively [65]. Natural fruit peel fermentation produces a low concentration of ethanol [66] of merely $5.4 \%$ to $13 \%$ at best, with the addition of dry yeast $[67,68]$. As this potential confounding factor is considered to be insignificant in previous studies, the alcohol concentration was hence not measured in the present study.

The $\mathrm{pH}$ of a solution may alter the antibacterial property of endodontic irrigants. However, the $\mathrm{pH}$ of our eco-enzyme was not determined in the present study. Fermented fruit peels eco-enzymes are generally acidic with $\mathrm{pH}$ ranges from 2.8 to $3.6[69,70]$, and this $\mathrm{pH}$ itself does not have significant antimicrobial properties against endodontic pathogenic microorganisms [58], including Enterococcus faecalis [71]. This finding is also in line with a study that reported that Enterococcus faecalis was able to tolerate the acidic environment at $\mathrm{pH}$ 2.9-4.2 [72].

There are several limitations to this study. Although endodontic infection is often polymicrobial, the pathogen studied in this research was confined to Enterococcus faecalis. Hence, an assumption could not be made as to whether eco-enzymes would exhibit similar antimicrobial activities against other endodontic pathogens. The study could be further improved by having another control group of fruit peels extract without fermentation, for a better comparison of active compounds which may affect antimicrobial efficacy against Enterococcus faecalis.

Further research is needed to explore the antimicrobial properties of the tested fruits in their natural state without fermentation as well as using various parts of the fruits as their antimicrobial nature has been established. Analysis by high-performance liquid chromatography (HPLC) is suggested to identify the major compounds contributing to the antimicrobial properties of the fruits. Purifying the identified compounds with potent antimicrobial agents could then be explored pharmaceutically for commercial purposes.

\section{Conclusions}

The present study showed that the concentration of P-EE and M-EE at 50\% and above exhibited significant antibacterial activity against Enterococcus faecalis. These results suggest that P-EE and M-EE could be exploited as a potential alternative to $\mathrm{NaOCl}$ as endodontic irrigants. However, further in vivo and clinical studies are required.

Author Contributions: Conceptualization: H.A.K.M., I.M.T., L.W., H.Z.Y., A.M., R.A.G., and E.H.N.P.; Methodology: H.A.K.M., I.M.T., and A.M.; Software: H.A.K.M. and I.M.T.; Validation: H.A.K.M., I.M.T., L.W., H.Z.Y., and A.M.; Formal analysis: H.A.K.M. and I.M.T.; Investigation: H.A.K.M. and I.M.T.; Resources: H.A.K.M. and I.M.T.; Data curation: H.A.K.M. and I.M.T.; Writing-original draft preparation: H.A.K.M., I.M.T., L.W., H.Z.Y., A.M., and R.A.G; Writing-review and editing: E.H.N.P.; Visualization: H.A.K.M., I.M.T., L.W., and E.H.N.P.; Supervision: I.M.T.; Project administration: H.A.K.M. and I.M.T.; Funding acquisition: H.A.K.M., I.M.T., L.W., H.Z.Y., A.M., and R.A.G. All authors have read and agreed to the published version of the manuscript.

Funding: This research was funded by UNIVERSITY RESEARCH GRANT (GUP-2018-144) from The National University of Malaysia.

Acknowledgments: We wish to convey our utmost appreciation and gratitude to Dr. Ng Meei Yi and all the staff at Microbiology Laboratory, Faculty of Dentistry, The National University of Malaysia for their assistance and support throughout this research study. 
Conflicts of Interest: The authors declare no conflict of interest.

\section{References}

1. Swimberghe, R.C.D.; Coenye, T.; De Moor, R.J.G.; Meire, M.A. Biofilm model systems for root canal disinfection: A literature review. Int. Endod. J. 2019, 52, 604-628. [CrossRef]

2. Alghamdi, F.; Shakir, M. The influence of Enterococcus faecalis as a dental root canal pathogen on endodontic treatment: A systematic review. Cureus 2020, 12, e7257. [CrossRef] [PubMed]

3. Nair, V.S.; Nayak, M.; Ramya, M.K.; Sivadas, G.; Ganesh, C.; Devi, S.L.; Vedam, V. Detection of adherence of Enterococcus faecalis in infected dentin of extracted human teeth using confocal laser scanning microscope: An in vitro study. J. Pharm. Bioall. Sci. 2017, 9, 41-44.

4. Zand, V.; Lotfi, M.; Soroush, M.H.; Abdollahi, A.A.; Sadeghi, M.; Mojadadi, A. Antibacterial efficacy of different concentrations of sodium hypochlorite gel and solution on Enterococcus faecalis biofilm. Iran Endod. J. 2016, 11, 315-319. [PubMed]

5. Estrela, C.; Estrela, C.R.A.; Barbin, E.L.; Spano, J.C.E.; Marchesan, M.A.; Pécora, J.D. Mechanism of action of sodium hypochlorite. Braz. Dent. J. 2002, 13, 113-117. [CrossRef] [PubMed]

6. Guivarc'h, M.; Ordioni, U.; Ahmed, H.M.A.; Cohen, S.; Catherine, J.-H.; Bukiet, F. Sodium hypochlorite accident: A systematic review. J. Endod. 2017, 43, 16-24. [CrossRef] [PubMed]

7. Choudhary, E.; Indushekar, K.R.; Saraf, B.G.; Sheoran, N.; Sardana, D.; Shekhar, A. Exploring the role of Morinda citrifolia and Triphala juice in root canal irrigation: An ex vivo study. J. Conserv. Dent. 2018, 21, 443-449.

8. Prabhakar, J.; Senthilkumar, M.; Priya, M.S.; Mahalakshmi, K.; Sehgal, P.K.; Sukumaran, V.G. Evaluation of antimicrobial efficacy of herbal alternatives (Triphala and Green Tea Polyphenols), MTAD, and 5\% sodium hypochlorite against Enterococcus faecalis biofilm formed on tooth substrate: An in vitro study. J. Endod. 2010, 36, 83-86. [CrossRef]

9. Radwan, I.N.; Randa, B.; Hend, A.N.; Camilia, G. Evaluation of antimicrobial efficacy of four medicinal plants extracts used as root canal irrigant on Enterococcus faecalis: An in vitro study. Int. Dent. Med. J. Adv. Res. 2015, 1, 1-8. [CrossRef]

10. Costa, E.M.; Evangelista, A.P.; Medeiros, A.C.; Dametto, F.R.; Carvalho, R.A. In vitro evaluation of the root canal cleaning ability of plant extracts and their antimicrobial action. Braz. Oral Res. 2012, 26, $215-221$. [CrossRef]

11. Saleem, M.; Saeed, M.T. Potential application of waste fruit peels (orange, yellow lemon and banana) as wide range natural antimicrobial agent. J. King Saud. Univ. Sci. 2020, 32, 805-810. [CrossRef]

12. Roy, S.; Lingampeta, P. Solid wastes of fruits peels as source of low cost broad spectrum natural antimicrobial compounds-Furanone, furfural and benezenetriol. Int. J. Res. Eng. Technol. 2014, 3, 273-279.

13. Martins, S.; Mussatto, S.I.; Martínez-Avila, G.; Montañez-Saenz, J.; Aguilar, C.N.; Teixeira, J.A. Bioactive phenolic compounds: Production and extraction by solid-state fermentation. A review. Biotechnol. Adv. 2011, 29, 365-373. [CrossRef] [PubMed]

14. Sadh, P.K.; Kumar, S.; Chawla, P.; Duhan, J.S. Fermentation: A boon for production of bioactive compounds by processing of food industries wastes (by-products). Molecules 2018, 23, 2560. [CrossRef] [PubMed]

15. Sagar, N.A.; Pareek, S.; Sharma, S.; Yahia, E.M.; Lobo, M.G. Fruit and vegetable waste: Bioactive compounds, their extraction, and possible utilization. Compr. Rev. Food Sci. Food Saf. 2018, 17, 512-531. [CrossRef]

16. Bhardwaj, A.; Ballal, S.; Velmurugan, N. Comparative evaluation of the antimicrobial activity of natural extracts of Morinda citrifolia, papain and aloe vera (all in gel formulation), 2\% chlorhexidine gel and calcium hydroxide, against Enterococcus faecalis: An in vitro study. J. Conserv. Dent. 2012, 15, 293-297. [CrossRef]

17. Duarte, M.A.H.; Yamashita, J.C.; Lanza, P.; Fraga, S.C.; Kuga, M.C. The influence of papain gel as endodontic irrigant in the apical leakage. Salusvita 2001, 20, 35-41.

18. Amri, E.; Mamboya, F. Papain, a plant enzyme of biological importance: A review. Am. J. Biochem. Biotechnol. 2012, 8, 99-104.

19. Pandey, S.; Cabot, P.J.; Shaw, P.N.; Hewavitharana, A.K. Anti-inflammatory and immunomodulatory properties of Carica papaya. J. Immunotoxicol. 2016, 13, 590-602. [CrossRef] 
20. Arun, C.; Sivashanmugam, P. Study on optimization of process parameters for enhancing the multi-hydrolytic enzyme activity in garbage enzyme produced from preconsumer organic waste. Bioresour. Technol. 2017, 226, 200-210. [CrossRef]

21. Gunwantrao, B.B.; Bhausaheb, S.K.; Ramrao, B.S.; Subhash, K.S. Antimicrobial activity and phytochemical analysis of orange (Citrus aurantium L.) and pineapple (Ananas comosus (L.) Merr.) peel extract. Ann. Phytomed. 2016, 5, 156-160. [CrossRef]

22. Li, T.; Shen, P.; Liu, W.; Liu, C.; Liang, R.; Yan, N.; Chen, J. Major polyphenolics in pineapple peels and their antioxidant interactions. Int. J. Food Prop. 2014, 17, 1805-1817. [CrossRef]

23. Ana, C.-C.; Jesus, P.-V.; Hugo, E.-A.; Teresa, A.-T.; Ulises, G.-C.; Neith, P. Antioxidant capacity and UPLC-PDA ESI-MS polyphenolic profile of Citrus aurantium extracts obtained by ultrasound assisted extraction. J. Food Sci. Technol. 2018, 55, 5106-5114. [CrossRef] [PubMed]

24. Liliany, D.; Widyarman, A.S.; Erfan, E.; Sudiono, J.; Djamil, M.S. Enzymatic activity of bromelain isolated pineapple (Ananas comosus) hump and its antibacterial effect on Enterococcus faecalis. Sci. Dent. J. 2018, 2, $41-52$.

25. Al Qarni, F.M.; Elfasakhany, F.M.; Kenawi, L.M.; Moustafa, A.M. Antimicrobial activity of Azadirachta indica (neem) and Salvadora persica (miswak) extracts as endodontic irrigants. Endo EPT 2019, 13, 237-245.

26. Basrani, B.; Tjaderhane, L.; Santos, J.M.; Pascon, E.; Grad, H.; Lawrence, H.P.; Friedman, S. Efficacy of chlorhexidine- and calcium hydroxide- containing medicaments against Enterococcus faecalis in vitro. Oral Surg. Oral Med. Oral Pathol. Oral Radiol. Endod. 2003, 96, 618-624. [CrossRef]

27. Diogo, P.; Mota, M.; Fernandes, C.; Sequeira, D.; Palma, P.; Caramelo, F.; Neves, M.G.P.M.S.; Faustino, M.A.F.; Goncalves, T.; Santos, J.M. Is the chlorophyll derivative $\mathrm{Zn}(\mathrm{II}) \mathrm{e}_{6} \mathrm{Me}$ a good photosensitizer to be used in root canal disinfection? Photodiagnosis Photodyn. Ther. 2018, 22, 205-211. [CrossRef]

28. Tawakoli, P.N.; Ragnarsson, K.T.; Rechenberg, D.K.; Mohn, D.; Zehnder, M. Effect of endodontic irrigants on biofilm matrix polysaccharides. Int. Endod. J. 2017, 50, 153-160. [CrossRef]

29. CLSI. Methods for Dilution Antimicrobial Susceptibility Tests for Bacteria that Grow Aerobically; Approved Standard: Ninth Edition; Clinical and Laboratory Standards Institute: Wayne, PA, USA, 2012; p. M07-A9.

30. Cieplik, F.; Kara, E.; Muehler, D.; Enax, J.; Hiller, K.-A.; Maisch, T.; Buchalla, W. Antimicrobial efficacy of alternative compounds for use in oral care toward biofilms from caries-associated bacteria in vitro. Microbiologyopen 2019, 8, e695. [CrossRef]

31. Kush, A.; Thakur, R.; Patil, S.D.S.; Paul, S.T.; Kakanur, M. Evaluation of antimicrobial action of Carie Care $^{\mathrm{TM}}$ and Papacarie Duo ${ }^{\mathrm{TM}}$ on Aggregatibacter actinomycetemcomitans a major periodontal pathogen using polymerase chain reaction. Contemp. Clin. Dent. 2015, 6, 534-538.

32. Lakhdar, L.; Farah, A.; Tahar, B.; Rida, S.; Bouziane, A.; Ennibi, O. In vitro antibacterial activity of essentials oils from Mentha pulegium, Citrus aurantium and Cymbopogon citratus on virulent strains of Aggregatibacter actinomycetemcomitans. Int. J. Pharmacog. Phytochem. Res. 2014, 6, 1035-1042.

33. Reddy, V.K.; Nagar, P.; Reddy, S.; Ragulakollu, R.; Tirupathi, S.P.; Ravi, R.; Purumadla, U. Bromelain vs. papain gel for caries removal in primary teeth. J. Contemp. Dent. Pract. 2019, 20, 1345-1349. [PubMed]

34. Praveen, N.C.; Rajesh, A.; Madan, M.; Chaurasia, V.R.; Hiremath, N.V.; Sharma, M.A. In vitro evaluation of antibacterial efficacy of pineapple extract (bromelain) on periodontal pathogens. J. Int. Oral Health 2014, 6, 96-98. [PubMed]

35. EUCAST. Determination of minimum inhibitory concentrations (MICs) of antibacterial agents by broth dilution: E.Dis 5.1. European Committee for Antimicrobial Susceptibility Testing (EUCAST) of the European Society of Clinical Microbiology and Infectious Diseases (ESCMID). Clin. Microbiol. Infect. 2003, 9, 1-7.

36. Neupane, K.; Khadka, R. Production of garbage enzyme from different fruit and vegetable wastes and evaluation of its enzymatic and antimicrobial efficacy. Tribhuvan Univ. J. Microbiol. 2019, 6, 113-118. [CrossRef]

37. Saramanda, G.; Kaparapu, J. Antimicrobial activity of fermented citrus fruit peel extract. Int. J. Eng. Res. Appl. 2017, 7, 25-28.

38. Rahman, S.; Haque, I.; Goswami, R.C.D.; Barooah, P.; Sood, K. Characterization and FPLC analysis of garbage enzyme: Biocatalytic and antimicrobial activity. Waste Biomass Valor. 2020. [CrossRef]

39. Balouiri, M.; Sadiki, M.; Ibnsouda, S.K. Methods for in vitro evaluating antimicrobial activity: A review. J. Pharm. Anal. 2016, 6, 71-79. [CrossRef] 
40. Basudan, S.O. Sodium hypochlorite use, storage, and delivery methods: A survey. Saudi. Endod. J. 2019, 9, $27-33$.

41. Dutner, J.; Mines, P.; Anderson, A. Irrigation trends among American Association of Endodontists members: A web-based survey. J. Endod. 2012, 38, 27-40. [CrossRef]

42. Gopikrishna, V.; Pare, S.; Pradeep Kumar, A.R.; Narayanan, L.L. Irrigation protocol among endodontic faculty and post-graduate students in dental colleges of India: A survey. J. Conserv. Dent. 2013, 16, 394-398. [CrossRef]

43. Basrani, B.; Haapasalo, M. Update on endodontic irrigating solutions. Endod Topics 2012, 27, 74-102. [CrossRef]

44. Iandolo, A.; Dagna, A.; Poggio, C.; Capar, I.; Amato, A.; Abdellatif, D. Evaluation of the actual chlorine concentration and the required time for pulp dissolution using different sodium hypochlorite irrigating solutions. J. Conserv. Dent. 2019, 22, 108-113. [CrossRef] [PubMed]

45. Mahmoud, Y.T.; Shehab, N.F.; Zakaria, N.A. Efficiency of sodium hypochlorite as root canal disinfectant against Enterococcus faecalis: An in vitro study. EC Microbiol. 2019, 15, 288-294.

46. Murad, C.F.; Sassone, L.M.; Souza, M.C.; Fidel, R.A.S.; Fidel, S.R.; Junior, R.H. Antimicrobial activity of sodium hypochlorite, chlorhexidine and $\mathrm{MTAD}^{\circledR}$ against Enterococcus faecalis biofilm on human dentin matrix in vitro. Rev. Bras. Odontol. 2012, 9, 143-150.

47. Ravinanthanan, M.; Hegde, M.N.; Shetty, V.; Kumari, S. Cytotoxicity effects of endodontic irrigants on permanent and primary cell lines. Biomed. Biotechnol. Res. J. 2018, 2, 59-62. [CrossRef]

48. Marion, J.J.C.; Manhães, F.C.; Bajo, H.; Duque, T.M. Efficiency of different concentrations of sodium hypochlorite during endodontic treatment. Literature review. Dent. Press Endod. 2012, 2, 32-37.

49. Verma, N.; Sangwan, P.; Tewari, S.; Duhan, J. Effect of different concentrations of sodium hypochlorite on outcome of primary root canal treatment: A randomized controlled trial. J. Endod. 2019, 45, 357-363. [CrossRef]

50. Yamashita, J.C.; Filho, M.T.; Leonardo, M.R.; Rossi, M.A.; Silva, L.A.B. Scanning electron microscopic study of the cleaning ability of chlorhexidine as a root-canal irrigant. Int. Endod. J. 2003, 36, 391-394. [CrossRef]

51. Muñoz, A.F.; Nolf, M.R.; Campusano, C.B.; Cea, D.C.; Cumsille, P.A.; Schnake, V.C.; Lopez, I.Y. Ethylenediaminetetraacetic acid as an irrigant between $5 \%$ sodium hypochlorite and $2 \%$ chlorhexidine in the formation of para-chloroaniline related precipitate. EC Dent. Sci. 2017, 10, 158-164.

52. Ketnawa, S.; Chaiwut, P.; Rawdkuen, S. Extraction of bromelain from pineapple peels. Food Sci. Technol. Int. 2011, 17, 395-402. [CrossRef] [PubMed]

53. Chaiwut, P.; Nitsawang, S.; Shank, L.; Kanasawud, P. A comparative study on properties and proteolytic components of papaya peel and latex proteases. Chiang Mai J. Sci. 2007, 34, 109-118.

54. Jayahari, N.K.; Niranjan, N.T.; Kanaparthy, A. The efficacy of passion fruit juice as an endodontic irrigant compared with sodium hypochlorite solution: An in vitro study. J. Investig. Clin. Dent. 2014, 5, 154-160. [CrossRef] [PubMed]

55. Seenivasan, R.; Roopa, L.; Geetha, S. Investigations on purification, characterization and antimicrobial activity of enzyme papain from Carica papaya Linn. J. Pharm. Res. 2010, 3, 1092-1095.

56. Molobela, I.P.; Cloete, T.E.; Beukes, M. Protease and amylase enzymes for biofilm removal and degradation of extracellular polymeric substances (EPS) produced by Pseudomonas fluorescens bacteria. Afr. J. Microbiol. Res. 2010, 4, 1515-1524.

57. Arun, C.; Sivashanmugam, P. Identification and optimization of parameters for the semi-continuous production of garbage enzyme from pre-consumer organic waste by green RP-HPLC method. J. Waste Manag. 2015, 44, 28-33. [CrossRef]

58. Lund, P.; Tramonti, A.; Biase, D.D. Coping with low pH: Molecular strategies in neutralophilic bacteria. FEMS Microbiol. Rev. 2014, 38, 1091-1125. [CrossRef]

59. Halstead, F.D.; Rauf, M.; Moiemen, N.S.; Bamford, A.; Wearn, C.M.; Fraise, A.P.; Lund, P.A.; Oppenheim, B.A.; Webber, M.A. The antibacterial activity of acetic acid against biofilm-producing pathogens of relevance to burns patients. PLoS ONE 2015, 10, e0136190. [CrossRef]

60. Arun, C.; Sivashanmugam, P. Solubilization of waste activated sludge using a garbage enzyme produced from different pre-consumer organic waste. RCS Adv. 2015, 5, 51421-51427. [CrossRef]

61. Verma, D.; Singh, A.N.; Shukla, A.K. Use of garbage enzyme for treatment of waste water. Int. J. Sci. Res. Rev. 2019, 7, 201-205. 
62. Mótyán, J.A.; Tóth, F.; Tőzsér, J. Research applications of proteolytic enzymes in molecular biology. Biomolecules 2013, 3, 923-942. [CrossRef] [PubMed]

63. Milošević, J.; Janković, B.; Prodanović, R.; Polović, N. Comparative stability of ficin and papain in acidic conditions and the presence of ethanol. Amino Acids 2019, 51, 829-838. [CrossRef] [PubMed]

64. dos Anjos, M.M.; da Silva, A.A.; de Pascoli, I.C.; Mikcha, J.M.G.; Machinski Jr, M.; Peralta, R.M.; de Abreu Filho, B.A. Antibacterial activity of papain and bromelain on Alicyclobacillus spp. Int. J. Food Microbiol. 2016, 216, 121-126. [CrossRef] [PubMed]

65. Man, A.; Gaz, A.S.; Mare, A.D.; Berta, L. Effects of low-molecular weight alcohols on bacterial viability. Rev. Rom. Med. Lab. 2017, 25, 335-343. [CrossRef]

66. Jayaprakashvel, M.; Akila, S.; Venkatramani, M.; Vinothini1, S.; Bhagat, S.J.; Hussain, A.J. Production of bioethanol from papaya and pineapple wastes using marine associated microorganisms. Biosci. Biotechnol. Res. Asia 2014, 11, 193-199. [CrossRef]

67. Girish, V.; Kumar, K.R.; Girisha, S.T. Estimation of sugar and bio ethanol from different decaying fruits extract. Adv. Appl. Sci. Res. 2014, 5, 106-110.

68. Khandaker, M.M.; Qiamuddin, K.; Majrashi, A.; Dalorima, T.; Sajili, M.H.; Hossain, A.S. Bio-ethanol production from fruit and vegetable waste by using Saccharomyces cerevisiae. Biosci. Res. 2018, 15, 1703-1711.

69. Rasit, N.; Mohammad, F.S. Production and characterization of bio catalytic enzyme produced from fermentation of fruit and vegetable wastes and its influence on aquaculture sludge. Int. J. Sci. Technol. 2018, 4, 12-26. [CrossRef]

70. Tang, F.E.; Tong, C.W. A study of the garbage enzyme's effects in domestic wastewater. Int. J. Environ. Ecol. Eng. 2011, 5, 887-892.

71. Morandi, S.; Brasca, M.; Alfieri, P.; Lodi, R.; Tamburini, A. Influence of $\mathrm{pH}$ and temperature on the growth of Enterococcus faecium and Enterococcus faecalis. Le Lait 2005, 85, 181-192. [CrossRef]

72. Mubarak, Z.; Soraya, C. The acid tolerance response and $\mathrm{pH}$ adaptation of Enterococcus faecalis in extract of lime Citrus aurantiifolia from Aceh Indonesia. F1000Research 2018, 7, 1-15. [CrossRef] [PubMed]

(C) 2020 by the authors. Licensee MDPI, Basel, Switzerland. This article is an open access article distributed under the terms and conditions of the Creative Commons Attribution (CC BY) license (http://creativecommons.org/licenses/by/4.0/). 